\title{
Thermal history recorded by the Apollo 17 impact melt breccia 73217
}

\author{
M.L. Grange ${ }^{1}$, A.A. Nemchin ${ }^{1}$, R.T. Pidgeon $^{1}$ N. Timms ${ }^{1}$, J.R. Muhling ${ }^{2}$ \& A. Kennedy ${ }^{3}$ \\ ${ }^{1}$ Department of Applied Geology, Western Australian School of Mines, Curtin University of \\ Technology, Bentley, Western Australia, 6102, Australia \\ ${ }^{2}$ Centre for Microscopy, Characterisation and Analysis, The University of Western Australia, \\ Crawley, Western Australia, 6009, Australia \\ ${ }^{3}$ Department of Imaging and Applied Physics, Curtin University of Technology, Bentley, \\ Western Australia, 6102, Australia
}

\begin{abstract}
Lunar breccia 73217 is composed of plagioclase and pyroxene clasts originating from a single gabbronorite intrusion, mixed with a silica-rich glass interpreted to represent an impact melt. A study of accessory minerals in a thin section from this breccia $(73217,52)$ identified three different types of zircon and anhedral grains of apatite which represent distinct generations of accessory phases and provide a unique opportunity to investigate the thermal history of the sample. Equant, anhedral zircons grains that probably formed in the gabbronorite, referred to as type-1, have consistent U-Pb ages of $4332 \pm 7$ Ma. A similar age of $4335 \pm 5$ Ma was obtained from acicular zircon (type-2) grains interpreted to have formed from impact melt. A polycrystalline zircon aggregate (type-3) occurs as a rim around a baddeleyite grain and has a much younger age of $3929 \pm 10 \mathrm{Ma}$, similar to the $3936 \pm 17$ Ma age of apatite grains found in the thin section. A combined apatite-type-3 zircon age of $3934 \pm 12$ Ma is proposed as the age of the Serenitatis impact event and associated thermal pulse. X-ray
\end{abstract}


mapping and electron probe analyses showed that $\mathrm{Ti}$ is inhomogeneous in the zircon grains on the sub-micron scale. However, model temperatures estimated from SHRIMP analyses of Ticoncentration in the 10 microns diameter spots on the polished surfaces of type- 1 and type- 2 zircons range between about $1300^{\circ} \mathrm{C}$ and $900^{\circ} \mathrm{C}$ respectively, while Ti-concentrations determined for the type-3 zircon are higher and correspond to the temperature of about 1400$1500^{\circ} \mathrm{C}$. A combination of U-Pb ages, Ti-concentration data and detailed imaging and petrographic studies of the zircon grains show that the gabbronorite parent of the zircon clasts formed shortly before the $4335 \pm 5$ Ma impact, which mixed the clasts and the felsic melt and projected the sample closer to the surface where fast cooling resulted in the crystallisation of acicular zircon (type-2). The 3934 \pm 12 Ma Serenitatis event resulted in partial remelting of the glass and formation of polycrystalline zircon (type-3). This event also reset the U-Pb system of apatite, formed merrillite coronas around some apatite grains and probably re-equilibrated some pyroxenes in the clasts. The age of the acicular zircon at $4335 \pm 5$ Ma provides the first evidence of pre-3.9 Ga impact melts. Our data, combined with other chronological results, demonstrate the occurrence of pre-3.9 Ga impacts on the Moon and suggest that the lunar impact history consisted of a series of intense bombardment episodes interspersed with relatively calm periods of low impact flux.

\section{INTRODUCTION}

Currently, the most widely accepted model for the impact history of the Moon is the Terminal Lunar Cataclysm or Late Heavy Bombardment (LHB) model in which the Moon and other planets in the inner Solar System experienced an intense bombardment over a short time period around 3.9 Ga following a long period of low impact flux (Tera et al., 1974). This model is supported by numerous Rb-Sr, K-Ar and Ar-Ar ages, including Ar-Ar ages of 3.75- 
3.96 Ga recently determined for 25 impact melt breccias from the Apollo 16 landing site (Norman et al., 2006). Current models of planetary motion also support the LHB hypothesis by providing a mechanism for the concentration of impacts within such a narrow time interval. These models suggest that rapid migration of giant planets could have triggered a massive delivery of planetesimals from the asteroid and cometary belts into the inner Solar System at about 3.9 Ga (Gomes et al., 2001). A second model of lunar impact history proposes that the meteorite flux was more evenly distributed through time and exponentially decayed from the original formation of the Solar System to the present. Geochronological support for this model is lacking, possibly because of the susceptibility of most mineral and rock isotopic systems to isotopic resetting under the extreme conditions generated by more recent impacts.

A significant exception is the U-Pb system of lunar zircon, which preserves a record of the pre-3.9 Ga lunar history (Meyer et al., 1996; Nemchin et al., 2008). The lack of evidence for zircon growth and/or resetting of older zircons associated with 3.9 Ga impacts confirms the stability of the zircon U-Pb system under shock associated with these impacts. In particular, zircons from Apollo 17 breccias show no evidence of events younger than $4186 \pm 7$ Ma (Nemchin et al., 2008). This age was determined for the impact-related reset part of a complex zircon found in an anorthosite clast in section 73235,82 (Pidgeon et al., 2007). The size of the zircon and its location within the anorthosite clast suggests excavation from substantial depth and that the $4186 \pm 7$ Ma impact was a significant event in the lunar history. Recently determined Ar-Ar ages for Apollo 16 and Apollo 17 samples were also interpreted as reflecting a major pre-LHB impact event at around 4.2 Ga (Fernandes et al., 2008).

These results from Apollo 17 breccias do not appear to be in accord with either model for lunar impact history and we have consequently undertaken a detailed investigation of the Ti concentrations and U-Pb ages of three morphological zircon types and co-existing apatite 
from an Apollo 17 impact melt breccia sample (thin section 73217,52) in an attempt to further elucidate the impact history of the breccia and the Apollo 17 region.

\section{ANALYTICAL TECHNIQUES}

\subsection{SEM imaging, EMPA and Electron backscatter diffraction (EBSD) mapping.}

Backscattered electron images of the sample were taken using Phillips XL30 SEM (20kV accelerating voltage, $15 \mathrm{~mm}$ working distance) at Curtin University of Technology.

X-Ray element maps for $\mathrm{K}, \mathrm{Ti}$ and $\mathrm{Zr}$ were collected with an automated JEOL JSM 6400 SEM fitted with three wavelength-dispersive spectrometers located in the Centre for Microscopy, Characterisation and Analysis at the University of Western Australia. Data were collected using the WD spectrometers with an accelerating voltage of $15 \mathrm{kV}$, beam current of $20 \mathrm{nA}$, pixel size of $\sim 1 \square \mathrm{m}$ and dwell time of $100 \mathrm{~ms}$ per pixel. Images were generated using software from Moran Scientific. Zircons were analysed for $\mathrm{Si}, \mathrm{Ti}$ and $\mathrm{Zr}$ on the same instrument using an accelerating voltage of $15 \mathrm{kV}$ and beam current of $20 \mathrm{nA}$, to maximise spatial resolution, using natural standards comprising wollastonite (Si), rutile (Ti) and zircon (Zr). Counting times of $40 \mathrm{~s}$ (peak) and $20 \mathrm{~s}$ (background) were used for $\mathrm{Si}$ and $\mathrm{Zr}$, and $300 \mathrm{~s}$ peak and background for Ti.

Prior to EBSD analysis, the sample was given an additional polish with $0.06 \mu \mathrm{m}$ colloidal silica $\mathrm{NaOH}$ (pH 9.8) suspension using a Buehler Vibromet II polisher for 3 hours to remove the surface damage from previous mechanical polishing, and given a thin $(\sim 1 \mathrm{~nm})$ carbon coat to reduced the effects of charging in the SEM chamber. Quantitative crystallographic orientation data was collected using EBSD via a Nordlys I detector attached to the Phillips XL30 SEM (Tungsten filament source, $20 \mathrm{kV}$ accelerating voltage, $20 \mathrm{~mm}$ 
working distance, $70^{\circ}$ tilt) at Curtin University using Oxford Instruments Channel 5 (SP9) software. Individual EBSPs were collected over an area (65x76 pixels at $1 \mu \mathrm{m}$ step size) and indexed using a match unit generated from zircon [2] of the MinCryst crystallographic database (Chichakov et al., 2001), which is optimal for analysis of most zircon (Reddy et al., 2008). Baddeleyite was indexed using the monoclinic $\mathrm{ZrO}_{2}$ match unit in the HKL phase database. The angular fit of the theoretical solution to the EBSP at each point was generally better than the $1.2^{\circ}$ user-defined tolerance in the mapping software, and averaged $0.64^{\circ}$ and $0.62^{\circ}$ for zircon and baddeleyite respectively. Isolated erroneous misindexed points were removed, and non-indexed points were filled to a five nearest neighbour solution, using procedure described in Reddy et al. (2007).

\subsection{Sensitive High-Resolution Ion MicroProbe (SHRIMP)}

Isotopic data were collected using the Sensitive High Resolution Ion Microprobe (SHRIMP II) based in the John de Laeter Centre of Mass Spectrometry, Perth, Western Australia. The SHRIMP methodology follows analytical procedure described elsewhere (Compston et al., 1984). The filtered $\mathrm{O}_{2}{ }^{-}$primary ion beam, with initial intensity between 2 and $3 \mathrm{nA}$, was reduced through Kohler aperture of $70 \mu \mathrm{m}$ to obtain a focused spot on the surface of samples of about $10 \mu \mathrm{m}$. This results in a decrease in intensity to $1.5 \mathrm{nA}$. Secondary ions were passed to the mass spectrometer operating at a mass resolution $(M / \Delta M$ at $1 \%$ ) of $~ 5000$. Each analysis was preceded by a 2 minutes raster to remove the Au coating and surface contamination.

The peak-hopping $\mathrm{U}-\mathrm{Pb}$ data collection routine consisted of seven scans through the mass stations, with signals measured by an ion counting electron multiplier. $\mathrm{Pb} / \mathrm{U}$ were calibrated using an empirical correlation between $\mathrm{Pb}^{+} / \mathrm{U}^{+}$and $\mathrm{UO}^{+} / \mathrm{U}^{+}$, normalised to the 564 
Ma Sri-Lankan zircon CZ3 (Pidgeon et al., 1994) while apatite analyses were corrected using 2058 Ma apatite crystal with $67 \mathrm{ppm}$ of $\mathrm{U}$ and ${ }^{206} \mathrm{~Pb} /{ }^{204} \mathrm{~Pb}$ of 500 . The 0.4 to $1.4 \%$ external 1sigma error obtained from the multiple analyses of $\mathrm{Pb} / \mathrm{U}$ on the standard during individual SHRIMP sessions was added in quadrature to the errors observed in the unknowns. The initial data reduction was done using the SQUID 2 add-in for Microsoft Excel and Isoplot (Ludwig, 2003) was applied for further age calculations.

The data collection routine for zircon Ti thermometry consisted of six scans through ${ }^{90} \mathrm{Zr}^{2+}$ and ${ }^{49} \mathrm{Ti}^{+}$mass stations, with signals measured by an ion counting electron multiplier. The $\mathrm{Ti}$ contents of unknowns were deduced from the relation $\left[(\mathrm{Ti} / \mathrm{Zr})_{\text {standard }} /(\mathrm{Ti} / \mathrm{Zr})_{\text {unknown }}\right]=\left(\mathrm{Ti}_{\mathrm{ppm}}\right)_{\text {standard }} /\left(\mathrm{Ti}_{\mathrm{ppm}}\right)_{\text {unknown }}$, where $\mathrm{Ti} / \mathrm{Zr}$ represent average of 6 scans and $\mathrm{Ti}_{\mathrm{ppm}}$ is the Ti concentration contents in standard and unknowns.

The zircon standard CZ3 was used as a reference for the calculation of Ti content of unknowns. Three $1 \mathrm{~mm}$ chips of CZ3 were analysed for Ti concentrations by LA-ICP-MS using an Excimer UV laser (193 nm), and a Hewlett-Packard Agilent 7500 quadrupole mass spectrometer, at the ANU. The analytical spot size was 45 micron diameter. The laser repetition rate was $4 \mathrm{~Hz}$, delivering $100 \mathrm{~mJ}$ per pulse. These analytical conditions were also used for the calibration and secondary standards. Ablation was conducted under a mixed $\mathrm{He}+\mathrm{H}_{2}$ atmosphere and the ablated material was carried to the plasma in an $\mathrm{Ar} / \mathrm{He}$ gas stream. The instrument was tuned to optimum sensitivity and to minimise production of interfering oxides species, with ${ }^{232} \mathrm{Th}^{16} \mathrm{O} /{ }^{232} \mathrm{Th}$ routinely $<0.5 \%$. The analyses were performed in peak hopping mode with a dwell time of $0.05 \mathrm{~s} /$ mass. For each analysis the gas blank was acquired for $30 \mathrm{~s}$, the laser triggered, and the signal acquired for a further 65-90 s. The analytical protocol essentially followed that of Eggins et al. (1998) and Norman et al. (2007). The primary calibrating standard was NIST-610 glass and the secondary standards, 91500 and BR266 zircon, BHVO-1, BIR-1, TB-1 and BCR-2 basalt glasses (Eggins 2003) were 
routinely analysed as unknowns to check data quality control. Batches of analyses of three to five “unknowns”' (the CZ3 zircon and the above-listed secondary standards) were bracketed by analyses of NIST-610 allowing monitoring of, and correction for, instrumental drift. Data reduction used background corrected count rates and the method established by Longerich et al. (1996). ${ }^{177} \mathrm{Hf}$ was measured enabling use of WDS electron microprobe determined $\mathrm{Hf}_{2} \mathrm{O}$ abundances as the internal reference element for zircons. Ti was measured at mass ${ }^{49} \mathrm{Ti}$, due to possible interferences on ${ }^{48} \mathrm{Ti}$. Calibration values for NIST-610 used in the data reduction are those of Eggins (2003). A linear drift correction based on the analysis sequence and on the bracketing analyses of NIST-612, was applied to the analyte count rate for each sample.

Multiple analyses of the secondary standard basaltic glasses indicated that analytical reproducibility and accuracy were better than 5\% for this analytical session. Four analyses of CZ3 give a mean Ti concentration of $5.05 \pm 0.6 \mathrm{ppm}$ (2 sig. uncertainty on the mean).

Temperature was calculated using equations defined by Watson et al. (2006). Errors estimated propagating analytical uncertainties are shown at 2-sigma level.

All errors for the U-Pb data obtained on individual SHRIMP spots are shown as 2sigma (unless specified), while errors of average ages are at 95\% confidence level.

\section{BRECCIA 73217}

Breccia sample 73217 (140g) was collected from the rim of a $10 \mathrm{~m}$ crater in the landslide material from the South Massif of the Apollo 17 landing site (Compston et al., 1984). It is described by Ishii et al. (1983) as a calcic-plagioclase-rich micro-breccia containing abundant angular mineral clasts and rare lithic clasts in a fine-grained, partially glassy matrix. From a study of the pyroxene clasts, these authors proposed that the mineral clasts in the breccia most likely originated from a fractionated (at temperatures of 1100- 
$1040^{\circ} \mathrm{C}$ ) relatively small layered intrusion. Many mineral clasts have thin rims formed postbrecciation by overgrowth or reaction (Ryder, 1993). In particular, Crawford (1975) described relict hypersthene as rimmed by a corona of small pigeonite and augite grains, where it comes in contact with the melt. Huber and Warren (2008) comment that relict pyroxenes are often mantled with a complex layer of altered or overgrown pyroxene that is more ferroan and more calcic in composition compared to relict grain cores.

Breccia 73217 has a complex matrix, described by Crawford (1975) as ranging in composition from dominantly micron-sized crushed granules of plagioclase and pyroxene to intergranular patches of glass which contains delicate acicular apatites. Crawford (1975) also described subhedral hypersthene crystals rimming melt patches and tiny hypersthene grains in the granulated matrix as elongate crystals rather than rounded grains, suggesting that recrystallisation followed granulation. Huber and Warren (2008) emphasised the strongly granitic composition of the glass and described long euhedral blades of ilmenite and occasionally Ca-phosphate in the glass. The occurrence of Fe-metal, troilite, and zircon in the glass was noted by Ishii et al. (1983).

On the basis of the presence of large plagioclase and exsolved pyroxene clasts, Crawford (1975) concluded that primary clasts material in the breccia equilibrated at ca $800^{\circ} \mathrm{C}$, in that part of the lunar crust where plutonic conditions prevail. Subsequently, the parent rocks were brecciated and partially melted. Their interpretation of the complexity of the pyroxene crystallisation trends led Ishii et al. (1983) to propose that the formation of the breccia involved an initial differentiation of basic magma into layers, a second event that mixed mineral clasts in only the upper part of the layered body, and a later thermal and brecciation episode involving mixing of lower and upper parts of the layered body. These authors remark that the above model is difficult to reconcile with the observed diffuse boundaries between clasts from the upper and lower parts of the layered body. They proposed 
that, during the mixing, temperatures of $1040^{\circ} \mathrm{C}$ to $1070^{\circ} \mathrm{C}$ caused partial melting to form glass and late stage accessory minerals crystallised as the melt cooled under near surface conditions (Ishii et al. 1983). However, Huber and Warren (2008) expressed doubts that the granitic glass could derive from partial melting of the gabbronorite parent of the clast population as suggested by Crawford (1975). They considered it more plausible to assume that the melt component was already molten before impact and subsequently mingled with the mafic rock fragments to form the breccia.

The contradicting features preserved in the sample therefore suggest that there is no genetic link between the clasts and the mesostasis, and that the gabbronoritic clasts, which represent a single slowly cooled plutonic body, were mixed with the melt component of 73217 as a result of impact followed by a rapid cooling due to projection of the clast-melt mixture closer to the surface (Huber and Warren, 2008).

SIMS U-Pb ages of four zircon grains from this breccia were reported by Compston et al. (1984). The grains were anhedral and showed evidence of resorption, presumably during the melting of the breccia matrix (Compston et al., 1984). The zoning patterns disrupted by grain boundaries indicate that the zircons are fragments of larger grains and therefore represent inherited clasts. One zircon grain is attached to an ilmenite clast suggesting that this grain and possibly the others belong to the clast population. A combined concordia intercept age of $4356_{-14}^{+23}$ Ma is one of the first reported from the ANU SHRIMP laboratory (Compston et al., 1984) and was interpreted as dating crystallisation of the gabbronorite.

\section{RESULTS}

\subsection{Zircon and apatite occurrence in thin section 73217,52}


An exceptional feature of the breccia exposed in thin section 73217,52 is that it contains three morphologically distinct zircon types which represent definite stages in the thermal history of the breccia. The first type (type-1) consist of rounded, anhedral 30 to 50 $\mu \mathrm{m}$ grains surrounded by glass (Fig. 1). The rounded zircon forms are similar to those of the pyroxene and apatite (Fig.1a) and it is possible these minerals represent a cogenetic group that crystallised from the impact melt at a relatively high temperature. Similar anhedral zircons have been found in impact melt in lunar meteorite SAU 169 (Gnos et al., 2004). The meteorite sample zircon is clearly intergrown with pyroxene and plagioclase leaving no doubt that it is an original component in the primary melt crystallisation sequence. However, the shapes of the type-1 zircon grains are similar to those reported by Compston et al. (1984) who interpreted these grains as having crystallised initially as euhedral crystals in the slowly cooling gabbronorite intrusion. Subsequently, the zircon grains have been rounded and embayed (Fig.1 a, d) by resorption in the surrounding felsic melt.

The second zircon type (type-2) is composed of several acicular zircons that have crystallised in the mesostasis together with needle-like ilmenite (Fig. 2). These zircons show perfect angular terminations with no evidence of resorption. While the origin of type- 1 zircon remains uncertain, the acicular grains have clearly crystallised from the felsic melt as it would be impossible to preserve the thin crystals intact if they existed prior to the impact that mixed gabbronoritic clasts with the felsic melt.

A third type of zircon (type-3) present in the breccia sample thin section 73217,52 occurs as a myriad of small crystals that form a reaction rim around a grain of baddeleyite (Fig. 3). This reaction corona consists of a polycrystalline aggregate of small rounded zircon grains. The irregular reaction front between the baddeleyite and the zircon mantle is interpreted as the limit of penetration of a dissolution-precipitation reaction process between the baddeleyite and the surrounding mixture of pyroxene and plagioclase clasts and very 
small pockets of glass, containing K-feldspar and needle-shaped ilmenite. In several places, glass penetrates deeply between the individual zircon grains and small rounded patches of baddeleyite remain stranded in the zircon corona, suggesting that the formation of zircon is a result of an in-situ reaction and replacement of baddeleyite, which was probably part of original gabbronorite.

Apatite and merrillite grains with irregular to subhedral shapes, resembling type-1 zircon grains, and large enough for ion probe analysis, were identified scattered throughout the mesostasis (Fig. 4). The observed intergrowths of apatite and pyroxene suggest that apatite formed in the gabbronorite and is part of the clast population. Some apatite grains are rimmed by clusters of small euhedral merrillite crystals oriented perpendicular to the apatite boundaries (Fig. 4b). This structure resembles the relationship between baddeleyite and its corona of zircon and is interpreted to have formed by the marginal breakdown of primary apatite under the same conditions responsible for formation of the zircon corona.

\subsection{U-Pb results}

Results of SHRIMP U-Pb analyses are given in Table 1. Compared to zircon that has an extremely low proportion of ${ }^{204} \mathrm{~Pb}$, with ${ }^{206} \mathrm{~Pb} /{ }^{204} \mathrm{~Pb}$ varying from 2410 to 79700 , the

apatite contains a larger amount of ${ }^{204} \mathrm{~Pb}$ with a ${ }^{206} \mathrm{~Pb} /{ }^{204} \mathrm{~Pb}$ between 410 and 4810 . Nevertheless, the common $\mathrm{Pb}$ in both apatite and zircon is sufficiently low to make contribution of uncertainty in the composition of initial $\mathrm{Pb}$ to the errors in the age determinations insignificant. The initial $\mathrm{Pb}$ correction for all analyses of zircons and apatites was made using modern common Pb composition (Stacey and Kramers, 1975), following the procedure of Nemchin et al. (2008), and assuming that most of the ${ }^{204} \mathrm{~Pb}$ in the lunar breccia sections represents terrestrial contamination. 
Multiple SIMS U-Pb analyses of acicular zircons (type-2) show slight scatter in ${ }^{238} \mathrm{U} /{ }^{206} \mathrm{~Pb}$ most likely resulting from the variation of relief around the grains due to uneven polishing of the lunar thin section. Nevertheless, essentially identical results are obtained from different methods of data treatment such as isochrons in ${ }^{207} \mathrm{~Pb} /{ }^{206} \mathrm{~Pb}-{ }^{238} \mathrm{U} /{ }^{206} \mathrm{~Pb}$ and ${ }^{207} \mathrm{~Pb} /{ }^{206} \mathrm{~Pb}-{ }^{204} \mathrm{~Pb} /{ }^{206} \mathrm{~Pb}$ coordinates or weighted average ages calculated from common $\mathrm{Pb}$ corrected ${ }^{207} \mathrm{~Pb} /{ }^{206} \mathrm{~Pb}$. However, the latter have been chosen as the most reliable estimates of ages considering that ${ }^{207} \mathrm{~Pb} /{ }^{206} \mathrm{~Pb}$ are independent on any uncertainties associated with the correction of $\mathrm{Pb} / \mathrm{U}$. Zircon and apatite analyses also reveal slight (about 2\%) reverse discordance of the data, which was explained by a slight difference in extraction of $\mathrm{U}$ and $\mathrm{Pb}$ from the sample and standard analysed in separate mounts (Nemchin et al., 2008). For this reason and considering that the thin section 73217,52 as well as all thin sections investigated by Nemchin et al. (2008) have been analysed against the same standard mount containing both zircon and apatite standards, the ratios ${ }^{238} \mathrm{U} /{ }^{206} \mathrm{~Pb}$ given in the Table 1 , as well as data on the Concordia diagram, have been increased by $2 \%$ to take this slight difference into account.

The data for ion probe spots on two type- 1 grains are identical and define an average ${ }^{207} \mathrm{~Pb} /{ }^{206} \mathrm{~Pb}$ age of $4332 \pm 7 \mathrm{Ma}$. Seven analyses of acicular zircons type-2 (Table 1 ) are also identical within the uncertainties and determine a similar average ${ }^{207} \mathrm{~Pb} /{ }^{206} \mathrm{~Pb}$ age of $4335 \pm 5$ Ma. Besides being essentially identical in age, the type- 1 and type- 2 grains have similar $U$ and Th contents with a Th/U ratio between 0.42 and 0.56 . However, SHRIMP U-Pb measurements on the small type-3 zircon grains surrounding the baddeleyite crystal record a markedly different age. The baddeleyite-zircon aggregate is about 50 microns in size, making precise positioning of ion probe spots difficult, and after-run imaging of the grains revealed that only two out of five analyses were positioned without overlapping the baddeleyite grain (Fig. 3c). An average of these two analyses gives a ${ }^{207} \mathrm{~Pb} /{ }^{206} \mathrm{~Pb}$ age of $3929 \pm 10$ Ma. Three other analyses overlap zircon and baddeleyite in different proportions. As a result, only a 
minimum age of $4275 \pm 20$ Ma was determined for the baddeleyite. However, it is likely that baddeleyite is at least as old as the older zircons.

${ }^{207} \mathrm{~Pb} /{ }^{206} \mathrm{~Pb}$ ages of SIMS analyses of five apatite and two merrillite grains are identical within the errors and the weighted average ${ }^{207} \mathrm{~Pb} /{ }^{206} \mathrm{~Pb}$ age of the seven analyses is $3936 \pm 17$ Ma. This age is indistinguishable from the age determined for the type-3 zircon surrounding the baddeleyite. The combined type-3 zircon and apatite data define an average age of $3934 \pm 12 \mathrm{Ma}$, which is interpreted as the best estimate of the last event preserved in sample 73217.

\section{3. $\mathrm{Ti}$ in zircon}

We have investigated the $\mathrm{Ti}$ concentrations in the three zircon types using X-ray mapping (Figs 1, 2 and 3), SHRIMP analyses (Table 1) and electron probe measurements (Table 2). The overall distribution of $\mathrm{Ti}$ in the zircon grains can be seen from the X-ray maps. They show what appears to be significant internal inhomogeneity in Ti concentration within the grains on the sub-micron scale, which is confirmed by Electron Microprobe Analyses (EMPA) data. EMPA study of the grains is possible because of the relatively high Ti-content of lunar zircon, although the accuracy of this analysis cannot be verified by analyses of relevant terrestrial zircon standards due to their low Ti-concentration. Seven spot analyses on type- 1 and four spots in type-2 zircon show extreme variation in $\mathrm{TiO}_{2}$ from below the detection limit (ca $10 \mathrm{ppm}$ ) to 1590 and 940 ppm respectively. $\mathrm{TiO}_{2}$ concentrations in the type-3 zircon appear to be higher, varying from 510 to $4100 \mathrm{ppm}$. The inhomogeneity shown by EMPA data contrasts with the relatively uniform Ti contents determined by SHRIMP analysis (Table 1). Clearly the inhomogeneity observed on the submicron scale is not evident on the scale of a SHRIMP spot (ca 10 micron diameter). 
Two SHRIMP analyses of the type- 1 zircons made in the same spots as U-Pb analyses determine identical temperatures of $1298 \pm 9^{\circ} \mathrm{C}$ and $1269 \pm 9^{\circ} \mathrm{C}$ (Watson et al., 2006). The concentration of Ti does not appear to be influenced by the presence of melt with higher Ticontent immediately around these grains. The after run secondary electrons (SE) images (Fig. 1b-c) indicate that the two Ti-analyses have been made entirely within the zircon and do not overlap the high-Ti melt outside, suggesting that the estimates of $\mathrm{Ti}$ concentrations in these grains do not have any analytical ambiguities. An average of two analyses equal to $1280 \pm 40^{\circ} \mathrm{C}$ is interpreted as the best estimate of the temperature of formation of type- 1 zircon. A very approximate temperature of $1090^{\circ} \mathrm{C}$, determined by averaging the 7 EMPA point analyses is viewed as supportive of the SHRIMP determination.

Three SHRIMP Ti analyses were made on acicular type-2 zircon (Table 1). Two of these analyses define similar temperatures of $917 \pm 7^{\circ} \mathrm{C}$ and $926 \pm 7^{\circ} \mathrm{C}$, while the third corresponds to a higher temperature of $1081 \pm 8^{\circ} \mathrm{C}$. It is not clear whether this difference reflects a real variation resulting from very fast cooling of the sample or is an artefact produced by a non complete equilibration of $\mathrm{Ti}$ in the zircon, also as a result of fast cooling of the rock. Nevertheless, a combination of all three analyses determines an average temperature of $975 \pm 180^{\circ} \mathrm{C}$, which appears to be lower than that determined for the type- 1 zircon, although the temperatures actually overlap within the errors. An approximate temperature of $1120^{\circ} \mathrm{C}$ determined from the 4 EMPA measurements on the acicular grain (Table 2) is consistent with the SHRIMP result.

The zircon-baddeleyite aggregate is surrounded by small (10-15 microns) euhedral pyroxene and plagioclase crystals with peripheral pockets of glass containing some Kfeldspars (Fig. 3). Although glass with higher Ti-concentration is not abundant at the contact with the analysed type-3 zircon, there are some small patches of what are possibly protrusions of melt into the zircon aggregate. In addition, baddeleyite in the centre of the aggregate has a 
much higher Ti content than the zircon corona (Fig. 3e). Therefore, it is possible that some of the $\mathrm{Ti}$ analytical spots represent mixtures between zircon and glass or zircon and baddeleyite, although analyses were made in the spots that have no indication of overlap with the baddeleyite grain in their U-Pb systems (Table 1). The three SHRIMP Ti analyses of type-3 zircon in the aggregate are very similar and define temperatures of $1420 \pm 10^{\circ} \mathrm{C}, 1525 \pm 11^{\circ} \mathrm{C}$ and $1594 \pm 11^{\circ} \mathrm{C}$ with an average of $1510 \pm 170^{\circ} \mathrm{C}$. Four EMPA Ti measurements on type-3 zircon grains define an average temperature of $1460^{\circ} \mathrm{C}$, which is consistent with the SHRIMP estimate and also indicates higher Ti content of these grains compared to the two other zircon types.

\section{DISCUSSION}

\subsection{A ca 4335 Ma impact melt}

Type-1 and -2 zircons are both surrounded by felsic glass containing K-Fsp crystals and have ages that are identical within the errors. However, while type-1 zircons occur as rounded anhedral grains the type-2 grains show extremely elongated, skeletal forms (Figs. 1, 2). These skeletal grains suggest crystallisation from the fast cooling felsic melt and their age of $4335 \pm 5$ Ma represents the time of melt solidification. Type- 1 zircons have identical ages, similar $\mathrm{U}$ and Th contents and similar model temperatures to the skeletal grains suggesting that these grains have also crystallised from the same melt. However, Compston et al. (1984) identified four zircon grains in other sections of breccia 73217, which they interpreted as originating from the parent gabbronorite, represented by the clast population in the breccia. This interpretation is based on the observation that one of these grains (70-80 $\mu \mathrm{m}$ in size) is an inclusion in an ilmenite of the clast assembly, while another one is a 120-150 $\mu \mathrm{m}$ zircon grain 
with a truncated optical zoning which is clearly a fragment of an even larger crystal. Accepting the Compston et al. (1984) interpretation, these two grains clearly predate formation of the felsic melt. Two remaining zircons identified by Compston et al. (1984) are groups of small $30 \mu \mathrm{m}$ grains similar to type-1 zircons from thin section 73127,52 . They are also surrounded by felsic melt and their origin is not completely constrained. However, the UPb systems of zircon grains analysed by Compston et al. (1984) fall on a discordia line that defines a concordia intercept at $4356_{-14}^{+23} \mathrm{Ma}$, which is similar to the age obtained for both our type-1 and type-2 zircon grains from section 73217,52. The coincidence of ages can be explained if the gabbronorite crystallised shortly before impact which then pulverised the gabbronorite and mixed the fragments with felsic melt to form the breccia. This was followed by rapid cooling to crystallise type- 2 zircons from the felsic glass. The alternative explanation, that both the rounded anhedral grains and the skeletal zircons crystallised from the granitic interstitial melt would need to disregard the textural evidence presented by Compston et al. (1984) and is considered less likely. Nevertheless, the present results provide the first demonstration of the presence of $4335 \pm 5$ Ma impact melt in a lunar breccia

\subsection{Formation of the type-3 zircon corona}

Whereas the age of the felsic melt at $4335 \pm 5$ Ma dates the formation of the impact breccia, the age of $3929 \pm 10$ Ma for the small type-3 zircons in the reaction corona, in combination with the identical $3936 \pm 17$ Ma age of apatite and merrillite from the same thin section, provides compelling evidence that a second major event has affected the breccia. The combined age of $3934 \pm 12$ Ma fits the accepted timing of terminal lunar cataclysm and is identical within the uncertainties to the age proposed for the Serenitatis impact (e.g. Stöffler et al., 2006) and is probably the best estimate of the age of this impact 
However, while the relatively weak U-Pb system of apatite could well have been reset during the thermal pulse generated by the Serenitatis impact, the interpretation of the young age of the corona zircon is not so evident. One explanation is that the coronas of zircon around the baddeleyite, merrillite reaction rims around apatite and the clinopyroxene rims around orthopyroxene clasts formed at $4335 \pm 5 \mathrm{Ma}$ as a result of chemical interaction between the felsic melt and the mineral clasts that originated from the gabbronorite intrusion. Subsequently, the U-Pb system of polycrystalline zircon around the baddeleyite grain was reset by the Serenitatis impact at $3934 \pm 12 \mathrm{Ma}$, whereas the larger type- 1 and -2 zircon grains were not isotopically disturbed.

An alternative explanation is that the coronas of zircon around the baddeleyite grain and similar merrillite coronas around apatite grains formed as a result of a solid state reaction between the primary minerals and the felsic glass at $3934 \pm 12$ Ma. Some of pyroxene clasts could also have re-equilibrated during this thermal event.

A resolution of which of these explanations is correct has profound implications for interpreting petrological relationships within the breccia and the breccia impact history.

Coronas of polycrystalline zircon around baddeleyite have been described by Davidson and van Bremen (1988) in metagabbros from the Grenville Province in Ontario. Baddeleyite and zircon from these rocks show significant difference in age which was interpreted as an indication that polycrystalline zircon rims formed around primary baddeleyite in response to increased silica activity during regional metamorphism. Different ages of baddeleyite cores and zircon rims were also recorded in the samples of Gairdner Dyke Swarm in South Australia (Wingate et al., 1997) and a number of other locations. As a result, the most common interpretation of zircon coronas around baddeleyite invokes reaction of the latter with metamorphic fluid enriched in silica. However, there are also observations of zircon rims similar in age to the baddeleyite cores (e.g. Santos et al., 2004). In this case, the 
similarity of ages suggests that zircon could form late in the magma crystallisation sequence as a result of reaction of baddeleyite with a fractionated more siliceous melt. It is evident that most of terrestrial examples of zircon corona formation around baddeleyite grains suggest crystallisation of zircon as a result of solid state reactions, supporting similar formation of zircon corona observed in the breccia thin section 73217,52.

\subsection{Ti-in-zircon thermometry}

The temperatures estimated by Ishii et al. (1983) from a combination of different pyroxene thermometers vary between $1100-1060^{\circ} \mathrm{C}$ to $1060-1050^{\circ} \mathrm{C}$ for different stages of crystallisation identified by these authors. They also suggest that different types of breccia identified within the sample 73217 experienced a later common annealing event at 1070$1040^{\circ} \mathrm{C}$. All these pyroxene data are close to the middle of the temperature range of 1300 to $900^{\circ} \mathrm{C}$ determined from the Ti-concentration in the type- 1 and -2 zircons. However, the Tizircon data are highly inhomogenous indicating that $\mathrm{Ti}$ was not completely equilibrated between the zircons and the parent melt probably as a result of relatively fast cooling, as the partial loss of Ti from zircon grains after their formation appears to be improbable according to the sluggish volume diffusion of Ti in zircon (Cherniak and Watson, 2007). Nevertheless, the SHRIMP Ti-data hint the possibility that the type-1 zircons could have formed at slightly higher temperature than the acicular type- 2 zircons. The temperature of $1500-1400^{\circ} \mathrm{C}$ determined for the type-3 zircon is significantly different from that recorded by the other two types. Even if this temperature is overestimated, the corresponding difference in the Ticoncentration indicates that the conditions were different during the formation of type-3 zircon and type-2 and -1 grains. Constraints on temperature formation of these minerals can be further investigated using $\mathrm{Pb}$ diffusion parameters in both zircons and apatite. 


\subsection{Pb diffusion constraints on the origin of type-3 zircon}

The key to resolving which of the two alternative explanation for the origin of the corona zircon is true, is whether it is possible that the small type-3 zircons in the corona can be completely reset under conditions of the Serenitatis impact, while the larger type- 1 and type-2 zircon grains remain closed isotopic systems. The difference in this resetting pattern can only be explained by the difference in the grain size. Type-1 zircons are about $25-30 \mu \mathrm{m}$ wide and about $50 \mu \mathrm{m}$ long, whereas the average size of zircon in the rim surrounding baddeleyite is about $5 \mu \mathrm{m}$. Assuming simple volume diffusion and spherical geometry the fraction of $\mathrm{Pb}$ loss can be estimated as:

$$
F=1-\frac{6}{\pi^{2}} \sum_{n=1}^{\infty} \frac{1}{n^{2}} \exp \left[\frac{-D n^{2} \pi^{2} t}{a^{2}}\right]
$$

where $F$ is a fraction of $\mathrm{Pb}$ loss, $D$ is diffusion coefficient, $a$ is effective radius of diffusion (i.e. radius of the sphere) and $t$ is time (e.g. Crank, 1975).

Based on the approximations of this equation derived by Reichenberg (1953), relationships between the radius of spherical grain and the fraction of lost $\mathrm{Pb}$ can be estimated for the relatively large and small loss as:

$$
\begin{aligned}
& \frac{D}{a^{2}}=\frac{1}{t}\left[\frac{2}{\pi}-\frac{2}{\pi}\left(1-\frac{\pi}{3} F\right)^{1 / 2}-\frac{1}{3} F\right] \quad \text { for } F \leq 0.85 \\
& \frac{D}{a^{2}}=\frac{-1}{\pi^{2} t} \ln \left[\frac{\pi^{2}}{6}(1-F)\right] \quad \text { for } F>0.85
\end{aligned}
$$


We apply equation 2 to $4335 \pm 12$ Ma, type 1 grains, which have retained their $\mathrm{Pb}$, and equation 3 to $3934 \pm 12$ Ma type 3 grains which, lost their $\mathrm{Pb}$ entirely during the Serenitatis impact event.

However, a Pb-loss of less than about $5 \%$ in the type- 1 grains will be difficult to detect as it would result in the reduction of ${ }^{207} \mathrm{~Pb} /{ }^{206} \mathrm{~Pb}$ age of a grain by about $16 \mathrm{Ma}$, whereas the total variation of ${ }^{207} \mathrm{~Pb} /{ }^{206} \mathrm{~Pb}$ ages determined for the type- 1 zircons is $18 \mathrm{Ma}$. Similarly, assuming that less than $5 \%$ residual fraction of $\mathrm{Pb}$ remaining in the zircon rim around baddeleyite will not change the ${ }^{207} \mathrm{~Pb} /{ }^{206} \mathrm{~Pb}$ age beyond the detectable limit, the minimum difference in radii of type- 1 and -3 zircons that will satisfy preservation of $\mathrm{U}-\mathrm{Pb}$ system in the former and resetting of this system in the later can be calculated by combining equations (2) and (3):

$$
\frac{a_{2}^{2}}{a_{1}^{2}}=-\pi^{2} \frac{\left[\frac{2}{\pi}-\frac{2}{\pi}\left(1-\frac{\pi}{3} F_{1}\right)^{1 / 2}-\frac{1}{3} F_{1}\right]}{\left.\ln \left[\frac{\pi^{2}}{6}\left(1-F_{2}\right)\right)\right]}
$$

For $F_{1}$ of $5 \%$ and $F_{2}$ of $95 \%$ this calculation suggests that unless the type- 1 grains are 30 times larger than the smaller grains in the rim, almost complete loss of $\mathrm{Pb}$ from the later should result in a not complete but clearly visible $\mathrm{Pb}$ loss in the larger grains. This estimate defines a minimum value for the difference as it is based on a generous assumption of $5 \%$ loss from what appears to be totally undisturbed grains and $5 \%$ residual $\mathrm{Pb}$ in the grains that appear to be completely reset. This calculation suggests that it is impossible to reset zircon rim without losing significant proportion of $\mathrm{Pb}$ from the other zircons. The only remaining explanation of observed chronological results is that the rim around the baddeleyite grain has 
formed at $3934 \pm 12$ Ma as a result of a reaction induced by the thermal pulse associated with the Serenitatis impact.

The formation of zircon coronas by reaction between baddeleyite and the surrounding silica-rich glass in response to what must have been a thermal pulse at $3934 \pm 12$ Ma represents the first report we are aware of, of solid-state zircon growth in an existing lunar breccia during a post-formation lunar impact. This raises the question of why the 3934 Ma thermal pulse did not recrystallise glass in the breccia sample at the same time as creating coronas around the clasts and some re-equilibration reactions in pyroxenes. The problem of preservation of vitreous glass patches in the sample can be resolved only if the late $3.9 \mathrm{Ga}$ event resulted in the partial remelting of the felsic glass.

\subsection{The thermal pulse at 3934 Ma}

Further assessment of the thermal history of the breccia sample at the time of the 3934 Ma impact can be modelled from equation (1) for a combination of apatite and zircon diffusion data (Cherniak et al. 1991; Cherniak and Watson 2001) and a similar set of assumptions regarding $\mathrm{Pb}$ loss, for type- 1 zircon grains and the largest apatite grain of about $120 \mu \mathrm{m}$ in size. The results of diffusion calculations of residence times for $\mathrm{Pb}$ in characteristic apatite and zircon grains in breccia 73217 for a range of temperatures are shown in Fig. 6 . The zircon curve (black) gives the time needed at a given temperature to lose $5 \%$ of its $\mathrm{Pb}$. The apatite curve (grey) gives the time required at a given temperature to lose $95 \%$ of its $\mathrm{Pb}$. The residence time trajectories place limits on the intensity and duration of the pulse associated with the 3934 \pm 12 Ma event. They indicate that the sample could not attain extremely high temperature during this event as, for example, at $2000^{\circ} \mathrm{C}$ zircon will lose $\mathrm{Pb}$ beyond the $5 \%$ limit within about 10 seconds and even at $1700^{\circ} \mathrm{C}$ it will take less than ten minutes to lose a 
detectable amount of $\mathrm{Pb}$ from the about $30 \mu \mathrm{m}$ zircon grains. These time intervals appear to be very short considering that the sample was not finely dispersed in the impact and it may take some time to dissipate heat if the sample was above $1700^{\circ} \mathrm{C}$ at any time. However, the estimated temperatures represent time integrated values meaning that the sample could have attained high temperatures for a few seconds and then cooled for a longer period of time. The true limit would be determined by the ability of the sample to dissipate heat. Regardless, the results indicate that $1700-1800^{\circ} \mathrm{C}$ is the limit for the temperature spike as higher temperatures will result in the severe $\mathrm{Pb}$ loss from the zircon in a matter of few minutes or less.

Resetting of apatite without affecting U-Pb system of zircon requires that the sample remained for substantial period of time at the intermediate temperatures. For example, at $1200^{\circ} \mathrm{C}$ the apatite U-Pb system will be reset within about a year while zircon will remain closed for diffusion. An additional limitation on the temperature attained by the sample is placed by the preservation of glass in the breccia 73217, suggesting that the sample was heated above the solidus of a silica-rich system of about $1000^{\circ} \mathrm{C}$. This, and constraints from the zircon and apatite curves indicate that, at $3934 \pm 12 \mathrm{Ma}$, the breccia sample experienced a thermal pulse to about $1250-1000^{\circ} \mathrm{C}$ for a time interval between a few years and a few thousand of years.

\section{IMPLICATIONS}

\subsection{History of breccia sample 73217}

Complexity of the sample 73217 and absence of experimental work on the behaviour of U-Pb system of zircon under the extreme shock associated with the large impacts prevent unique interpretation of some data obtained for this sample. Because no relationships between 
the type- 1 zircons and the minerals representing clast population have been observed in the studied thin sections, these zircon grains can be interpreted as crystallised from the felsic melt. Alternatively they could have formed in the gabbronorite and became broken and resorbed during the mixing of different components of the breccia sample. Available experimental data for $\mathrm{Pb}$ diffusion in zircon suggest that the zircon corona around baddeleyite grain formed during the last thermal event experienced by the sample. This conclusion is also supported by the high Ti concentration observed in the type-3 zircon compared to that of type- 1 and 2 grains. The difference indicates different conditions of crystallisation of type-3 zircon and therefore provides independent evidence of their formation during the late $3.9 \mathrm{Ga}$ event. However, the experimental data are more suitable for a relatively slow increase and relaxation of P-T pulse characteristic of terrestrial metamorphism and melting. Under these conditions, pressure is not considered to be a major factor of $\mathrm{Pb}$ diffusion. There is a substantial difference between this relatively slow process and shock generated during an impact where extreme pressure and temperature can be attained for a very short period of time. It is possible that under these conditions behaviour of U-Pb system in zircon is very different. As a result the possibility that the small polycrystalline zircons lost their Pb while other zircon grains preserved their original ages cannot be completely excluded.

Nevertheless, based on the currently available information, the data obtained for the breccia sample 73217 indicate that a gabbronorite source of clasts crystallised shortly before the formation of breccia at $4335 \pm 5$ Ma. In addition to plagioclase and pyroxene, the gabbronorite contained variety of accessory phases, including apatite, baddeleyite and zircon. It is possible that these minerals formed late in the crystallisation history of gabbronorite. An impact at $4335 \pm 5$ Ma brecciated gabbronorite, mixed fragments with a felsic melt and propelled the mixture closer to the lunar surface, where the molten part of the breccia crystallised very quickly resulting in the preservation of glass with only minor development 
of very elongated and often skeletal crystals of K-feldspar, ilmenite and zircon. The shape of these grains indicates crystallisation from the supercooled liquid. The second thermal pulse associated with the $3934 \pm 12$ Ma Serenitatis impact reheated the sample to the temperatures between about 1250 and $1000^{\circ} \mathrm{C}$ for a time period between several years to several thousand of years. This heating probably resulted in the partial remelting of the felsic glass which reacted with some of the clasts forming coronas of zircon around baddeleyite and merrillite around apatite as well as re-equilibrating some pyroxene clasts and resetting U-Pb systems of all apatite grains.

\subsection{Bombardment history of the Moon}

Although some interpretations of data obtained for the sample 73217 remain controversial, elongated, acicular zircon of type- 2 clearly crystallized from the felsic melt inside the breccia sample, suggesting that an impact occurred at $4335 \pm 5$ Ma. In addition, apatite grains define $\mathrm{U}-\mathrm{Pb}$ age of $3936 \pm 17 \mathrm{Ma}$ indicating complete $\mathrm{Pb}$-loss during the Serenitatis impact. These results have profound implications for the understanding of impact history of the Moon. First of all, resetting of apatite U-Pb ages during the $3934 \pm 12 \mathrm{Ma}$ impact while the U-Pb system of zircon remained intact suggests that some Ar-Ar ages obtained for the other breccia samples from the Apollo collection supporting a 3.9 Ga LHB model could also have been reset. Therefore, a number of samples containing impact melts predating LHB can have been placed into the 3.9 Ga group on the basis of Ar-Ar data, recording resetting event instead of true impact melt crystallisation. In addition, even if the original interpretation of the mesostasis representing an impact melt (Ishii et al., 1983) is not correct and the felsic melt existed before mixing with the gabbronorite component of the sample, a peripheral impact is still necessary to bring the two components together and accommodate the fast 
cooling rates after mixing (Huber and Warren, 2008). The implied change from slow to fast cooling rate requires a significant change in the depth of magma crystallisation before and after the impact. This suggests a substantial energy of impact and therefore a significant size of the impactor. The $4335 \pm 5$ Ma age defines the time of this major impact event. This age is not unique in the analysed zircon population from Apollo 17 breccias. A large and old zircon fragment ( $>0.5 \mathrm{~mm},>4.44 \mathrm{Ga}$ ) was identified in the matrix of breccia sample 72215 , collected about $3 \mathrm{~km}$ to the south-west of the 73217 location (Nemchin and Pidgeon, 2008). Resetting of part of this zircon due to impact-related crystal-plastic deformation occurred at $4333 \pm 7$ Ma. The size of the grain indicates very slow original crystallisation from magma at substantial depth. Impact-related exhumation from depth and ductile deformation of this grain is evidence of a significant, high energy, impact at this time. Recent zircon and Ar-Ar age determinations also provide evidence of large impacts predating LHB (Fernandes et al., 2008; Nemchin et al., 2008). The overall zircon age distribution patterns show peaks at about 4.354.30 and 4.25-4.20 Ga (Nemchin et al., 2008), indicating discrete pulses in the post Lunar Magma Ocean magmatism on the Moon. It is possible that these pulses were activated by the periodic increase in meteorite flux creating instability in the upper mantle and triggering segregation and emplacement of magma into the lunar crust. A combination of recent zircon and Ar-Ar data suggests that at least two major impact episodes predated the LHB at about 4.35-4.30 and 4.25-4.20 Ga and that the impact history of the Moon consisted of a number of intense bombardment episodes interspersed with relatively calm periods when the flux of meteorites temporarily subsided. The relative intensity of these episodes is difficult to estimate as the overall chronological data base is heavily biased towards the younger Ar-Ar ages. It is still possible that the $3.9 \mathrm{Ga}$ event dominates the bombardment history. It is equally possible that the periodicity of impacts is superimposed on an overall decaying flux of 
impactors, i.e. the 4.35-4.30 Ga event was more intense than 4.25-4.20 Ga and the final 3.9 Ga episodes.

\section{CONCLUSIONS}

Textural observations have revealed the presence of three generations of zircon and anhedral apatite in the breccia thin section 73217,52 . This has provided a unique opportunity to investigate the thermal history of this breccia using a combination of imaging techniques, $\mathrm{U}-\mathrm{Pb}$ ages and $\mathrm{Ti}$ concentrations of these minerals together with their known diffusion properties. The data indicate that the clast population formed at $1280 \pm 40^{\circ} \mathrm{C}$, shortly before a major impact at $4335 \pm 5$ Ma which mixed clasts with a felsic melt. Crystallisation of skeletal blades and needles of K-feldspar, ilmenite and zircon, occurred at $970 \pm 180^{\circ} \mathrm{C}$ during rapid cooling of the melt which was quenched to form a silica-rich glass. This represents the first reliable dating of melt generated by a lunar impact at $4335 \pm 5 \mathrm{Ma}$. The breccia experienced a second thermal event at $3934 \pm 12$ Ma with temperatures in the range of $1250-1000^{\circ} \mathrm{C}$ for up to several thousand years, which at least partially remelted the glass, caused widespread reaction between minerals and surrounding matrix producing coronas of zircon around baddeleyite and merrillite around apatite and reset the $\mathrm{U}-\mathrm{Pb}$ systems of apatite. The interpretation of type-3 zircons age, as dating solid-state zircon growth at the expense of baddeleyite during the ca 3.9 Ga Serentiatis event, is the first impact-related zircon record in the Apollo 17 region.

Several observations cannot be interpreted unambiguously on the basis of currently available data. For instance it is not certain that equant and rounded type- 1 zircon grains, interpreted to have crystallised in the gabbronorite prior to impact, did not actually crystallise in the impact melt. Also, new experimental data on $\mathrm{Pb}$ diffusion in zircon subjected to the extreme shock during the impacts is necessary to confirm our interpretation of the origin of 
the polycrystalline zircon corona around the baddeleyite grain. Nevertheless, the evidence of 4335 \pm 5 Ma impact preserved in breccia sample 73217 combined with other data indicating pre-3.9 Ga impacts on the Moon question the validity of the LHB hypothesis. New U-Pb and Ar-Ar ages obtained for a number of lunar samples do not support either the LHB model or a model that the inner Solar System was subjected to an exponentially decaying flux of impactors. Instead these new results suggest that the Moon experienced several periods of intense bombardment interspersed with the intervals characterised by the limited number of impacts.

\section{Acknowledgments}

We would like to thank Apollo 17 astronauts who risked their lives to collect samples. This project was supported by the Office of Research and Development of Curtin University of Technology. Nick Timms acknowledges funding from ARC Discovery Project 0664078. 


\section{REFERENCES}

Cherniak D.J., Lanford W.A., and Ryerson F.J. (1991) Lead diffusion in apatite and zircon using ion implantation and Rutherford Backscaterring techniques. Geochim. Cosmochim. Acta 55, 1663-1673.

Cherniak D.J. and Watson E.B. (2001) Pb diffusion in zircon. Chem. Geol., 172, 5-24.

Cherniak D.J. and Watson E.B. (2007) Ti diffusion in zircon. Chem. Geol., 242, 470-483.

Chichagov, A.V., et al. (2001) MINCRYST: a crystallographic database for minerals, local and network (WWW) versions. Crystallography Reports 46, 876-879.

Compston W., Williams I.S. and Meyer C. (1984) U-Pb geochronology of zircons from Lunar Breccia 73217 using a sensitive high mass-resolution ion microprobe, Proc. Lunar Planet. Sci. Conf. $14^{\text {th }}$, J. Geophys. Res. 89, B525-534.

Crawford M.L. (1975) Magma genesis by in-situ melting within the Lunar crust. Proc. Lunar Sci. Conf. 6, 249-261.

Crank J. (1975) Mathematics of Diffusion, $2^{\text {nd }}$ ed. Oxford University Press, London.

Davidson A. and van Bremen O. (1988) Baddeleyite-zircon relationships in coronitic metagabbro, Grenville Province, Ontario: implications for geochronology. Contrib. Mineral. Petrol. 100, 291-299.

Eggins S.M. (2003). Laser ablation ICP-MS analysis of geological materials prepared as lithium borate glasses. Geostandards Newsletter, The Journal of Geostandards and Geoanalysis, 27, 147-162.

Eggins, S. M., Kinsley, L. P. J., and Shelley, J. M. G. (1998). Deposition and element fractionation processes during atmospheric pressure laser sampling for analysis by ICPMS. Applied Surface Science, 127-129, 278-286 
Fernandes V.A., Garrick-Bethell D.L., Shuster D.L. and Weiss W. (2008) Common 4.2 Ga impact age in samples from Apollo 16 and 17. Workshop on the Early Solar System Impact Bombardment Abstract \#3028.

Gnos E., Hofmann B.A., Al-Katgiri A., Lorenzetti S., Eugster O., Whitehouse M.J., Villa I.M., Jull A.J.T., Eikenberg J., Spettel B., Krähenbühl U., Franchi I.A. and Greenwood R.C. (2004) Pinpointing the source of a lunar meteorite: Implications for the evolution of the Moon. Science 305, 657-659.

Gomes R., Levison H.F., Tsiganis K. and Morbidelli A. (2005) Origin of the cataclysmic Late Heavy Bombardment eprid of the terrestrial planets. Nature 435, 466-469.

Huber H. and Warren P.H. (2008) Enigmatic, largely granitic 73217: A lunar mixed meltbreccia, but is it impact melt? LPSC XXXIX Houston, USA, Abstract \#2405.

Ishii T., McCallum S. and Ghose S. (1983) Petrological and thermal histories of Lunar breccia 73217 as inferred from pyroxene crystallization sequences, exsolution phenomena, and pyroxene geothermometry. Proc. Lunar Sci. Conf. 13, A631-A644.

Longerich, H.P., Jackson, S.E. and Gunter, D. (1996). Laser ablation inductively coupled plasma mass spectrometric transient signal data acquisition and analyte concentration calculation. Journal of analytical atomic spectrometry, 11, 613-904

Ludwig K.R. (2003) User’s Manual for Isoplot 3.00. Berkeley Geochronological Center Special Publication, pp 74.

Nemchin A.A. and Pidgeon R.T. (2008) Lunar cataclysm or lunar cataclysms? LPSC XXXIX Houston, USA, Abstract \#1558.

Nemchin A.A., Pidgeon R.T., Whitehouse M.J., Vaughan J.P. and Meyer C. (2008) SIMS U$\mathrm{Pb}$ study of zircon from Apollo 14 and 17 breccias: Implications for the evolution of lunar KREEP. Geochim. Cosmochim. Acta 72, 668-689. 
Norman, M.D., Pearson, N.J., Sharma, A., Griffin, W.L. (2007). Quantitative analysis of trace elements in geological materials by laser ablation ICPMS: instrumental oprating conditions and calibration values of NIST glasses. Geostandards and Geoanalytical Research, 20, 247-261

Norman M.D., Duncan R.A. and Huard J.J. (2006) Identifying impact events within the lunar cataclysm from ${ }^{40} \mathrm{Ar}-{ }^{39} \mathrm{Ar}$ ages and compositions of Apollo16 impact melts rocks. Geochim. Cosmochim. Acta 70, 6032-6049.

Meyer C., Williams I.S. and Compston W. (1996) Uranium-lead ages for lunar zircons: Evidence for a prolonged period of granophyre formation from 4.32 to 3.88 Ga. Meteoritics Planet. Sci. 31, 370-387.

Pidgeon R.T., Furfaro D., Kennedy A.K., Nemchin A.A. and van Bronswjk W. (1994) Calibration of zircon standards for the Curtin SHRIMP. In: 8th Int. Conf. on Geochronology, Cosmochronology and Isotope Geology, Berkeley, U.S. Geol. Surv. Circ. 1107, pp 251.

Pidgeon R.T., Nemchin A.A., van Bronswijk W., Geisler T., Meyer C., Compston W. and Williams I. (2007) Complex history of a zircon aggregate from lunar breccia 73235. Geochim. Cosmochim. Acta 71, 1370-1381.

Reddy S.M., Timms N.E., Pantleon W. and Trimby T. (2007) Quantitative characterization of plastic deformation of zircon and geological implications. Contrib. Mineral. Petro. 153, 625-645.

Reddy S.M., Timms N.E. and Eglington, B.M. (2008) Electron backscatter diffraction analysis of zircon: a systematic assessment of match unit characteristics and pattern indexing optimization. American Mineralogist 93, 187-197.

Reichenberg D. (1953) Properties of ion exchange resins in relation to their structure. III. Kinetics of exchange. J. Am. Chem. Soc. 75, 589-597. 
Santos J.O.S., Van Breemen O.B., Groves D.I., Hartmann L.A., Almeida M.E., McNaughton N.J. and Fletcher I.R. (2004) Timing and evolution of multiple Paleoproterozoic magmatic arcs in the Tapajós Domain, Amazon Craton: constraints from SHRIMP and TIMS zircon, baddeleyite and titanite U-Pb geochronology, Prec. Res. 131, 73-109

Stacey J.S. and Kramers J.D. (1975) Approximation of terrestrial lead isotope evolution by a two-stage model. Earth Planet. Sci. Lett. 26, 207-221.

Stöffler D., Ryder G., Ivanov B.A., Artemieva N.A., Cintala M.J. and Grieve R.A.F. (2006) Cratering History and Lunar Chronology, In New Views of the Moon. Rev. Mineral. Geochem., Mineralogica Society of America 60, Chapter 5, 519-596.

Tera F., Papanastassiou D. and Wasserburg G.J. (1974) Isotopic evidence for a terminal lunar cataclysm. Earth Planet. Sci. Lett. 22, 1-21.

Watson E.B., Wark D.A. and Thomas J.B. (2006) Crystallization thermometers for zircon and rutile, Contrib. Mineral. Petrol. 151, 413-433.

Wingate M.T.D., Campbell I.H., Compston W. and Gibson G.M. (1998) Ion microprobe U$\mathrm{Pb}$ ages for Neoproterozoic basaltic magmatism in south-central Australia and implications for the breakup of Rodinia, Prec. Res., 87, 135-159 


\section{FIGURE CAPTIONS}

Figure 1. Images of type-1 zircon. (a) Back-Scattered Electron (BSE) image of zircon in its textural context; zrc, zircon; plag, plagioclase; K-fs, K-feldspar; px, pyroxene; ap, apatite; mer, merrillite; gl, glass. The black zone is the resin. Circles indicate the location of the two SHRIMP analyses. (b) and (c) Detailed BSE images of U-Pb and Ti SHRIMP analysis locations. Each analysis spot is around 5-7 $\mu \mathrm{m}$. (d), (e), (f) WDS maps of Zr, Ti and K concentration, respectively, of area indicated by white box on (a). Relative concentration is shown on scale on the right. $\mathrm{K}$ relative concentration gives a good proxy to identify the position of glass, containing 7.50\%.wt of $\mathrm{K}_{2} \mathrm{O}$ (Huber and Warren, 2008).

Figure 2. Images of type-2 zircon. (a) BSE image of zircon group-2 in its textural context. Legend as in Fig. 1a; ilm, ilmenite. (b) and (c) Legend as in Fig. 1b-c. Spots 2-6 and 2-7 have been analysed for a previous study (Nemchin et al., 2008); spot 2-6 represent the real size of the spot without the rastered zone and spot 2-7 is located in the same place as spot 2-2. (d), (e), (f) Legend as in Fig 1.

Figure 3. Images of baddeleyite surrounded by zircon rim. (a) BSE image of baddeleyite surrounded by zircon, in its textural context. Legend as Figs. 1 and 2. (b) EBSD map of baddeleyite and polycrystalline aggregate zircon showing variation in crystalline orientations of area indicated by black box on (a). (c) Detailed BSE images of U-Pb and Ti SHRIMP analysis locations. (d), (e), (f) Legend as in Fig 1.

Figure 4. Images of apatite 9. (a) BSE image of apatite 9 in its textural context. Legend as in Fig.1a. (b) Optical image of apatite 9 in transmitted light (plane polarisation) 
illustrating the relationships between apatite and merrillite. Small euhedral merrillite crystals grow normal to the apatite grain. Circles and numbers on both (a) and (b) indicate locations and names of SHRIMP analyses.

Figure 5. U-Pb SHRIMP results for zircons and apatites of breccia thin section 73217,52. Data corrected for initial $\mathrm{Pb}$ are shown on the Tera-Wasserburg concordia diagram. All error ellipses are of $2 \sigma$ uncertainty. Red ellipses represent analyses on type- 1 zircon; green ellipses represent analyses on type-2 zircon. Blue ellipses represent baddeleyite-zircon aggregate analyses; the oldest gives the minimum age assigned to baddeleyite, the two youngest are zircon analyses defining time of resetting, and the two intermediate ones give mixed ages between baddeleyite and zircon. Grey ellipses represent 7 analyses on apatites.

Figure 6. Temperatures and time constraints for the U-Pb systems resetting. The curves indicate T-t conditions required to allow diffusion of lead in a $30 \mu \mathrm{m}$ zircon (black curve) and $120 \mu \mathrm{m}$ apatite (grey curve). The curves are constrained according to the equations (2) and (3) for apatite and zircon respectively (see text). The approximate dry granite solidus is given as a benchmark for the partial melting of the felsic glass of the breccia 73217. The hatched zone corresponds to the conditions required to allow complete resetting of $\mathrm{U}-\mathrm{Pb}$ in apatite, no resetting of this system in zircon and partial melting of the glass, according to our results.

Figures 


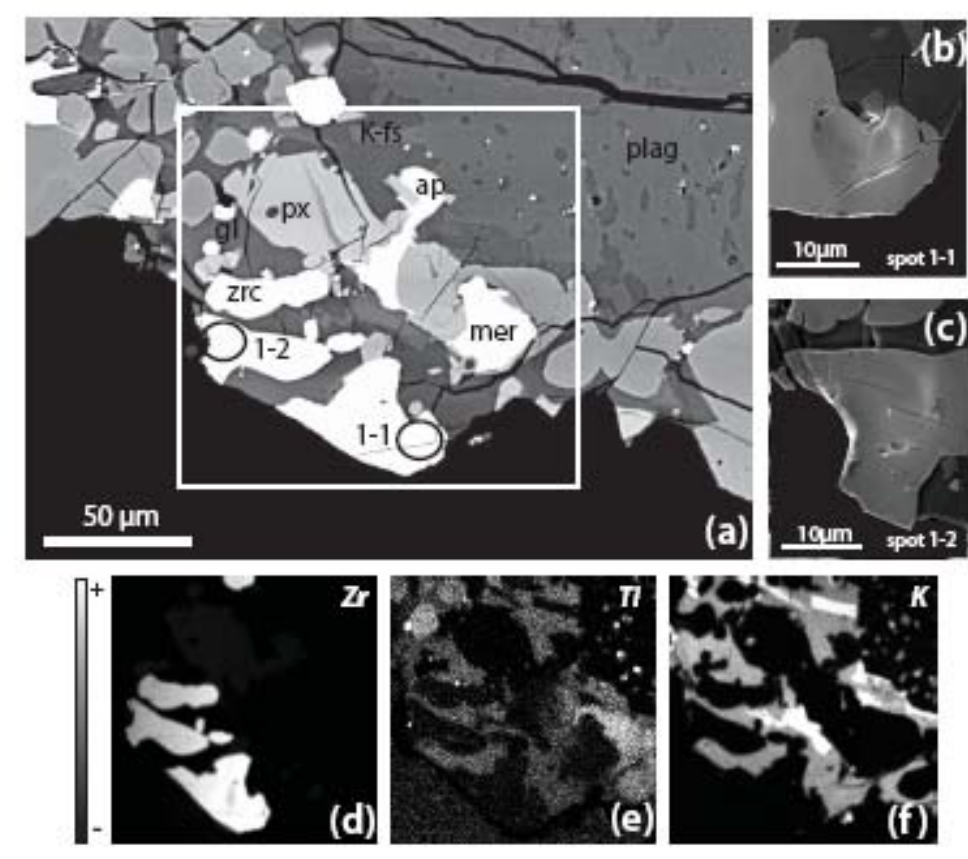

Figure 1
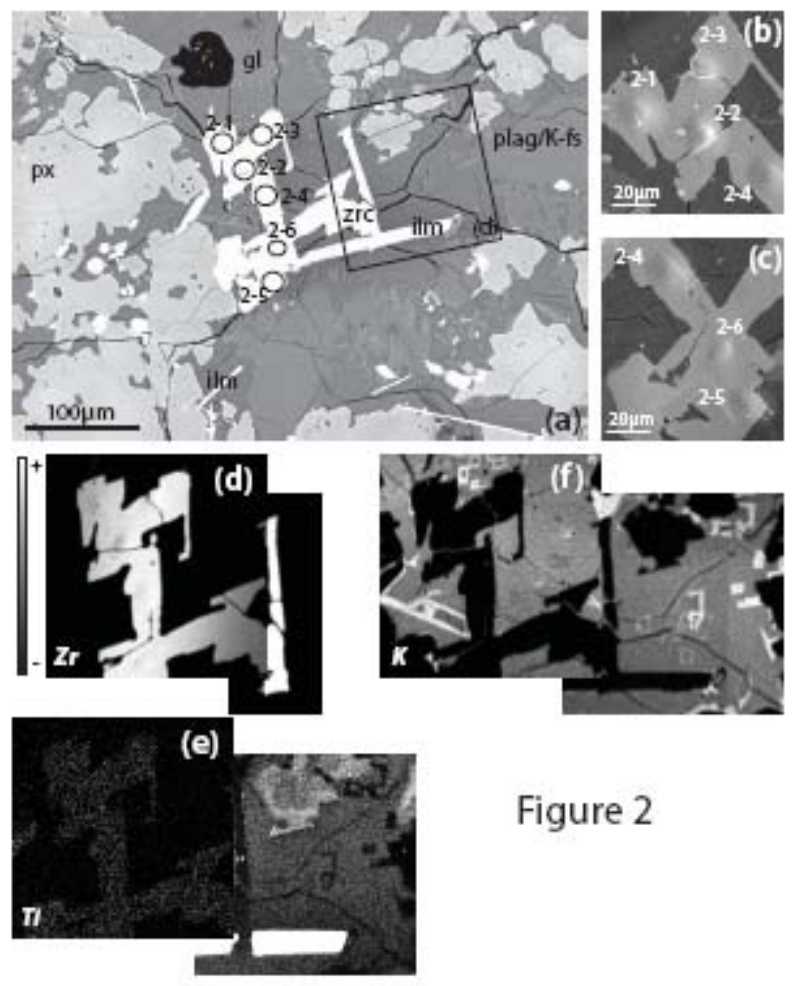

Figure 2 


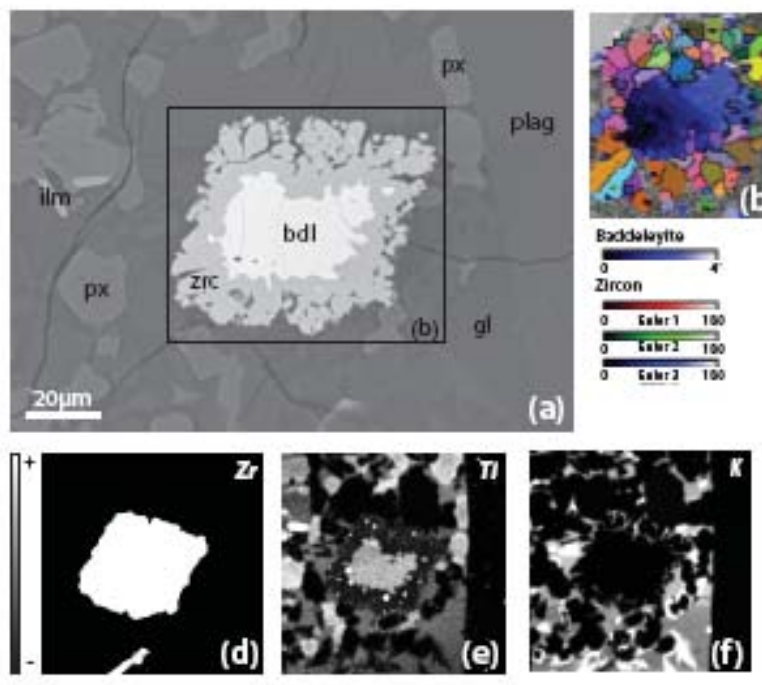

Figure 3
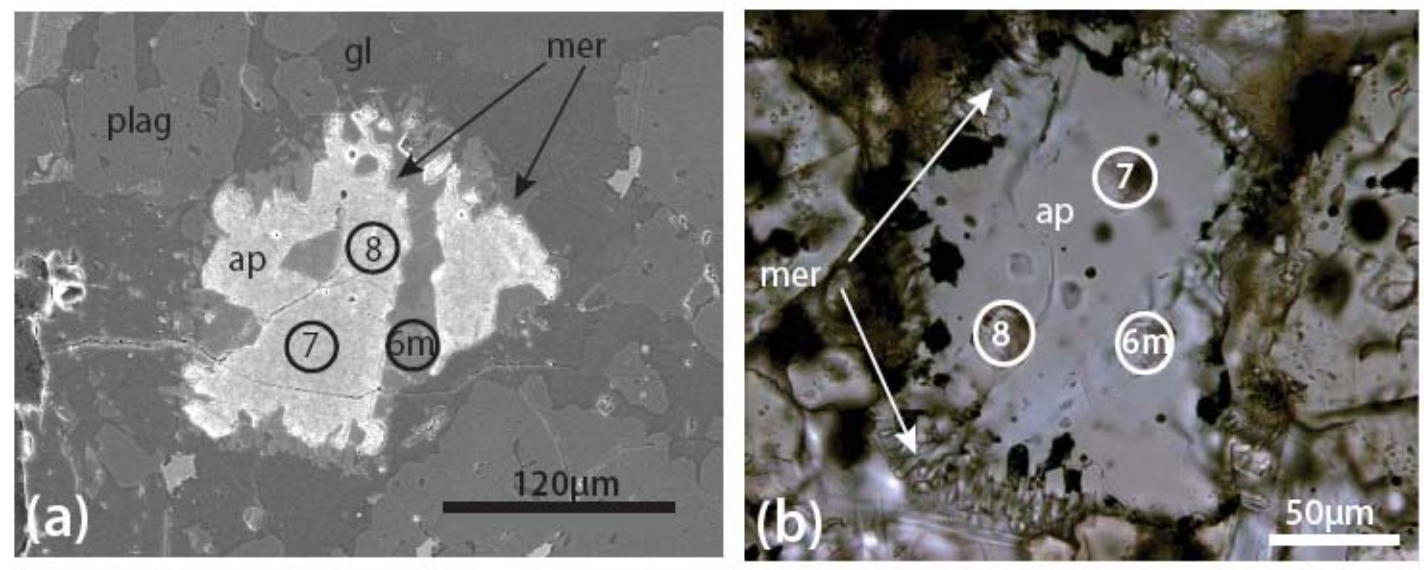

Figure 4 


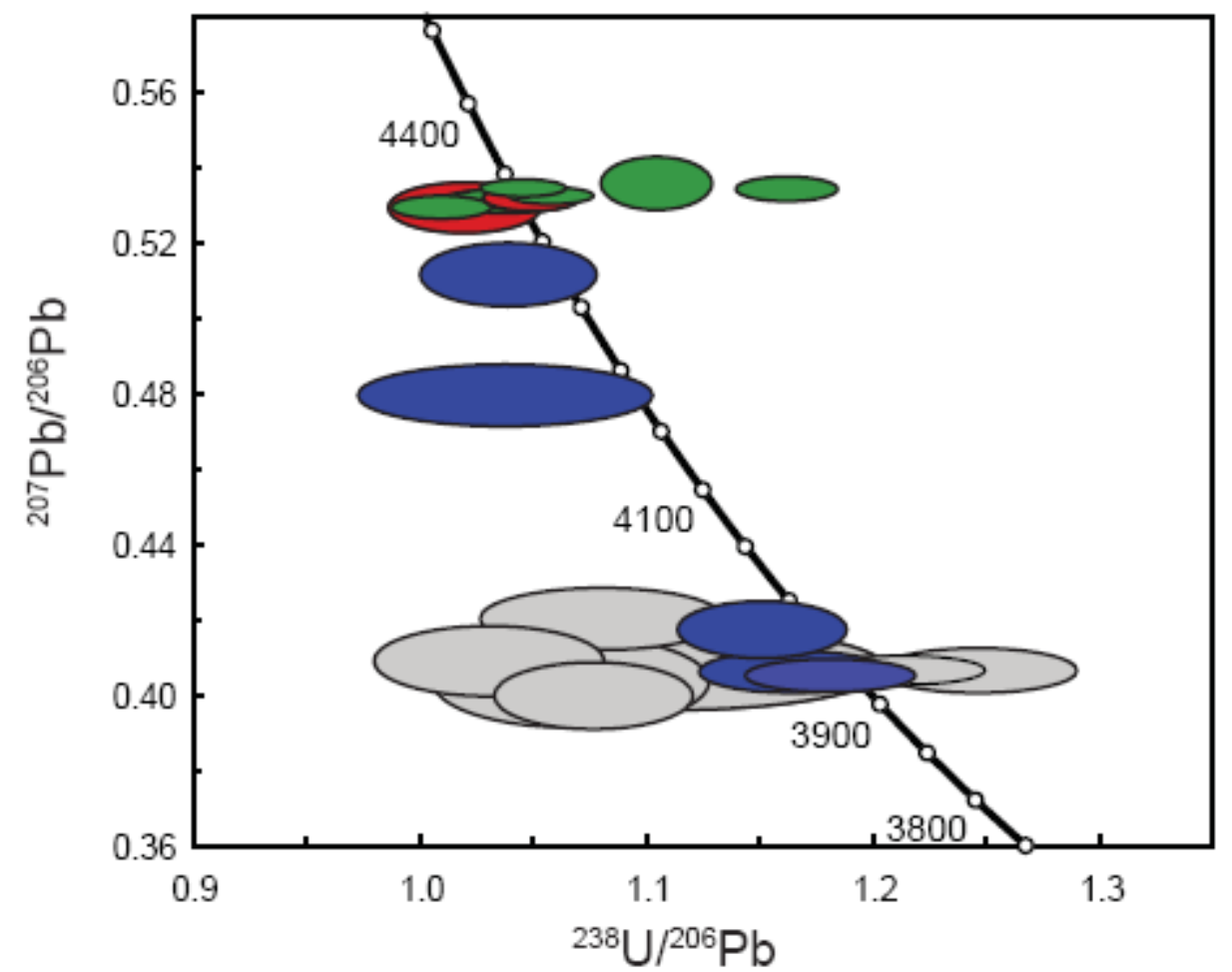

Figure 5

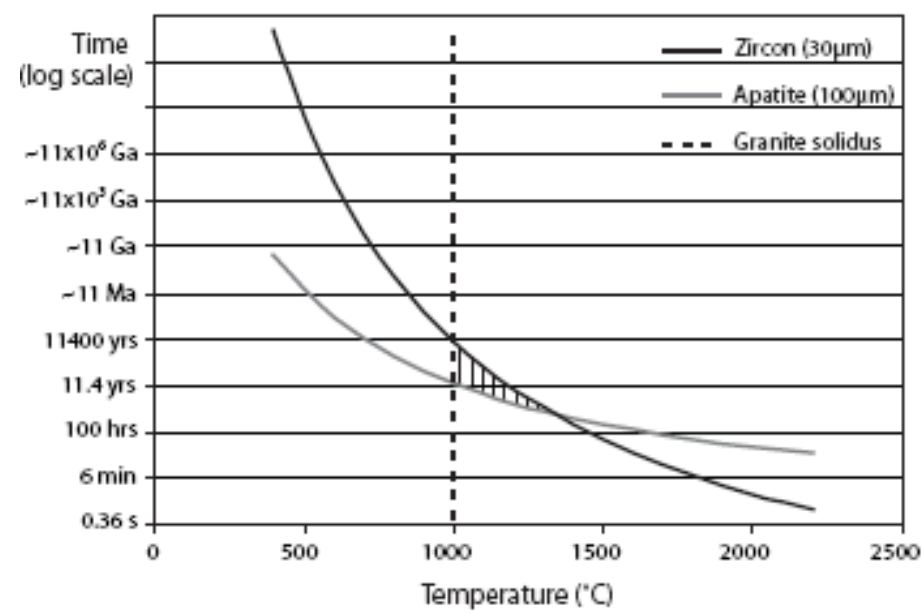

Figure 6 


\begin{tabular}{|c|c|c|c|c|c|c|c|c|c|c|c|c|c|c|c|c|c|}
\hline \multirow{4}{*}{$\begin{array}{l} \\
\text { Mineral } \\
\text { spots }\end{array}$} & \multirow{4}{*}{$\begin{array}{l}\mathrm{U} \\
\text { (ppm) }\end{array}$} & \multirow{4}{*}{$\begin{array}{l}\text { Th } \\
\text { (ppm) }\end{array}$} & \multirow{4}{*}{$\frac{{ }^{232} \mathrm{Th}}{{ }^{238} \mathrm{U}}$} & \multirow{4}{*}{$\frac{206 \mathrm{~Pb}}{{ }^{206} \mathrm{~Pb}}$} & \multirow{4}{*}{$\frac{{ }^{207} \mathrm{~Pb}}{{ }^{206} \mathrm{~Pb}}$} & \multirow{3}{*}{$\begin{array}{l}\text { err } \% \\
1 \sigma\end{array}$} & \multirow{3}{*}{$\frac{{ }^{208} \mathrm{~Pb}}{{ }^{206} \mathrm{~Pb}}$} & \multirow{3}{*}{$\begin{array}{l}\text { err } \% \\
10\end{array}$} & \multirow{3}{*}{$\begin{array}{l}\frac{238 \mathrm{U}}{{ }^{206} \mathrm{~Pb}} \\
\text { total }\end{array}$} & \multirow{3}{*}{$\begin{array}{l}\text { err } \% \\
1 \sigma\end{array}$} & \multicolumn{4}{|c|}{${ }^{204} \mathrm{~Pb}$ corrected ${ }^{(0)}$} & \multirow{3}{*}{$\begin{array}{l}\frac{207 \mathrm{~Pb}^{x}}{{ }^{206} \mathrm{~Pb}^{x}} \\
\text { (age Ma) }\end{array}$} & \multirow{2}{*}{\multicolumn{2}{|c|}{ Ti-in-zircon }} \\
\hline & & & & & & & & & & & \multirow{2}{*}{$\frac{{ }^{206} \mathrm{~Pb}^{x}}{{ }^{206}}$} & \multirow{2}{*}{$\begin{array}{l}\text { err } \% \\
1 \sigma\end{array}$} & \multirow{2}{*}{$\frac{{ }^{238} \mathrm{U}}{{ }^{206} \mathrm{pb}^{x}}$} & \multirow{2}{*}{$\begin{array}{l}\text { err \% } \\
10\end{array}$} & & & \\
\hline & & & & & & & & & & & & & & & & $\mathrm{ppm}^{(d)}$ & $T^{\circ} \mathrm{C}^{(e)}$ \\
\hline & & & & & & & & & corre & cted for & the $2 \%$ re & eversed & discordar & & & & \\
\hline zircon type-1 & & & & & & & & & & & & & & & & & \\
\hline $217-1-1$ & 196 & 94 & 0.50 & 4080 & 0.5337 & 0.25 & 0.131 & 1.08 & 1.045 & 0.83 & 0.5322 & 0.26 & 1.049 & 0.84 & $4333 \pm 4$ & 592 & $1296 \pm 9$ \\
\hline $\begin{array}{l}217-1-2 \\
\text { zircon type-2 }\end{array}$ & 154 & 62 & 0.42 & 2700 & 0.5318 & 0.50 & 0.111 & 1.32 & 1.013 & 1.32 & 0.5298 & 0.52 & 1.019 & 1.34 & $4326 \pm 8$ & 515 & $1267 \pm 9$ \\
\hline $217-2-1$ & 289 & 156 & 0.56 & 15490 & 0.5332 & 0.17 & 0.143 & 0.70 & 1.056 & 0.72 & 0.5328 & 0.17 & 1.058 & 0.72 & $4335 \pm 2$ & 55 & $816 \pm 7$ \\
\hline $217-2-2$ & 163 & 78 & 0.50 & 15270 & 0.5348 & 0.25 & 0.134 & 1.08 & 1.160 & 0.78 & 0.5344 & 0.25 & 1.181 & 0.79 & $4339 \pm 4$ & 179 & $1079 \pm 8$ \\
\hline $217-2-3$ & 176 & 91 & 0.53 & 6570 & 0.5307 & 0.23 & 0.137 & 0.98 & 1.007 & 0.88 & 0.5297 & 0.24 & 1.009 & 0.89 & $4326 \pm 3$ & - & - \\
\hline $217-2-4$ & 135 & 55 & 0.42 & 6210 & 0.5371 & 0.53 & 0.111 & 1.15 & 1.101 & 0.90 & 0.5361 & 0.54 & 1.104 & 0.80 & $4344 \pm 8$ & 59 & $925 \pm 7$ \\
\hline $217-2-5$ & 259 & 133 & 0.53 & 34920 & 0.5350 & 0.18 & 0.136 & 0.74 & 1.045 & 0.74 & 0.5348 & 0.18 & 1.045 & 0.74 & $4340 \pm 3$ & - & - \\
\hline $217-2-8^{(\mathbf{s})}$ & 186 & 82 & 0.50 & 44670 & 0.5321 & 0.22 & 0.123 & 0.51 & 1.042 & 1.07 & 0.5319 & 0.23 & 1.042 & 1.07 & $4332 \pm 3$ & - & - \\
\hline $\begin{array}{l}217-2-7^{(\circledR)} \\
\text { zircon type-3 }\end{array}$ & 169 & 90 & 0.53 & 79700 & 0.5314 & 0.24 & 0.135 & 0.72 & 1.037 & 1.12 & 0.5313 & 0.24 & 1.037 & 1.12 & $4331 \pm 3$ & - & - \\
\hline $217-3-1$ & 74 & 46 & 0.84 & 3900 & 0.4072 & 0.43 & 0.175 & 1.51 & 1.175 & 1.28 & 0.4051 & 0.45 & 1.181 & 1.30 & $3928 \pm 7$ & 1013 & $1418 \pm 10$ \\
\hline $217-3-2$ & 41 & $B$ & 0.14 & 2300 & 0.5145 & 0.60 & 0.044 & 7.55 & 1.031 & 1.47 & 0.5117 & 0.67 & 1.039 & 1.52 & $4275 \pm 10$ & - & \\
\hline $217-3-3$ & 56 & 35 & 0.85 & 4040 & 0.4192 & 0.53 & 0.203 & 1.74 & 1.145 & 1.24 & 0.4172 & 0.75 & 1.151 & 1.33 & $3972 \pm 11$ & 1928 & $1591 \pm 11$ \\
\hline $217-3-4$ & 31 & 8 & 0.28 & 1430 & 0.4844 & 0.82 & 0.104 & 2.92 & 1.025 & 2.53 & 0.4795 & 0.71 & 1.038 & 2.56 & $4179 \pm 10$ & - & - \\
\hline $\begin{array}{l}217-3-5 \\
\text { apatite } 14\end{array}$ & 65 & 50 & 0.79 & 2410 & 0.4095 & 0.48 & 0.213 & 1.82 & 1.156 & 1.44 & 0.4080 & 0.57 & 1.184 & 1.46 & $3932 \pm 9$ & 1517 & $1523 \pm 11$ \\
\hline $\begin{array}{l}73217-52-4 \\
\text { apatite } 9\end{array}$ & 5 & 468 & 89.1 & 900 & 0.4125 & 0.83 & 15.437 & 1.85 & 1.044 & 2.21 & 0.4034 & 1.24 & 1.068 & 2.33 & $3922 \pm 19$ & & \\
\hline $73217-52-6 \mathrm{~m}$ & 69 & 190 & 2.87 & 4810 & 0.4081 & 0.38 & 0.591 & 2.05 & 1.208 & 1.22 & 0.4085 & 0.38 & 1.213 & 1.22 & $3933 \pm 6$ & & \\
\hline $73217-52-7$ & 7 & 400 & 59.1 & 1330 & 0.4148 & 0.82 & 10.073 & 0.62 & 1.016 & 1.98 & 0.4088 & 0.94 & 1.030 & 2.01 & $3942 \pm 14$ & & \\
\hline $73217-52-8$ & 12 & 452 & 38.0 & 1740 & 0.4114 & 1.07 & 8.150 & 2.13 & 1.097 & 3.51 & 0.4088 & 1.10 & 1.109 & 3.51 & $3934 \pm 17$ & & \\
\hline $\begin{array}{l}73217-52-9 \\
\text { apatite } 4\end{array}$ & 14 & 528 & 39.6 & 1920 & 0.4039 & 0.88 & 6.621 & 0.40 & 1.086 & 1.58 & 0.3998 & 0.92 & 1.078 & 1.86 & $3908 \pm 14$ & & \\
\hline $73217-52-10 \mathrm{~m}$ & 37 & 99 & 2.78 & 410 & 0.4259 & 0.49 & 0.591 & 0.70 & 1.189 & 1.38 & 0.4063 & 0.60 & 1.248 & 1.43 & $3932 \pm 9$ & & \\
\hline $73217-52-11$ & 9 & 556 & 67.0 & 960 & 0.4282 & 0.71 & 10.797 & 0.92 & 1.059 & 2.01 & 0.4200 & 0.80 & 1.080 & 2.03 & $3982 \pm 12$ & & \\
\hline data publishe & $\mathrm{din} N$ & chin & 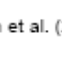 & 08) & ots & 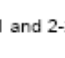 & . & & & & & & & & & & \\
\hline odata correctec & & & mon 1 & using & acey & & odel & & & & & & & & & & \\
\hline & & & & & & & & & & & & & & & & & \\
\hline & & & & & & & & & & & & & & & & & \\
\hline peratures & (n) & & & & & & & & & & & & & & & & \\
\hline
\end{tabular}

Table 2: EMPA results for zircons from breccia sample 73217,52 (EMP data).

\begin{tabular}{|c|c|c|c|c|c|c|c|c|}
\hline $\begin{array}{l}\text { Minerals } \\
\operatorname{spot}^{(a)}\end{array}$ & $\begin{array}{l}\mathrm{SiO}_{2} \\
\text { Wt.\% }\end{array}$ & $\begin{array}{l}\text { err } \\
2 \sigma\end{array}$ & $\begin{array}{l}\mathrm{ZrO}_{2} \\
\text { Wt.\% }\end{array}$ & $\begin{array}{l}\text { err } \\
2 \sigma\end{array}$ & $\begin{array}{l}\mathrm{TiO}_{2} \\
\mathrm{ppm}\end{array}$ & $\begin{array}{l}\text { err } \\
2 \sigma\end{array}$ & Total & $\begin{array}{l}\text { err } \\
2 \sigma\end{array}$ \\
\hline zircon type-1 & & & & & & & & \\
\hline zrc1-1 & 32.81 & 0.16 & 65.49 & 1.57 & 360 & 120 & 98.33 & 1.58 \\
\hline zrc1-2 & 32.73 & 0.16 & 62.17 & 1.51 & 1590 & 120 & 95.06 & 1.52 \\
\hline zrc1-3 & 32.11 & 0.16 & 63.06 & 1.53 & 30 & 70 & 95.17 & 1.54 \\
\hline zrc1-4 & 30.22 & 0.16 & 63.25 & 1.53 & $<$ d.I. & - & 93.47 & 1.54 \\
\hline zrc1-5 & 33.03 & 0.17 & 63.51 & 1.54 & 120 & 70 & 96.55 & 1.55 \\
\hline zrc1-6 & 32.70 & 0.16 & 63.61 & 1.54 & $<$ d.I. & - & 96.31 & 1.55 \\
\hline zrc1-7 & 31.88 & 0.16 & 62.10 & 1.51 & 100 & 70 & 93.99 & 1.52 \\
\hline & \multicolumn{6}{|c|}{ Average $\mathrm{Ti}(\mathrm{ppm})=264$} & \multicolumn{2}{|c|}{$\mathrm{T}\left({ }^{\circ} \mathrm{C}\right)=1088$} \\
\hline zircon type-2 & & & & & & & & \\
\hline zrc2-1 & 32.11 & 0.16 & 62.43 & 1.52 & $<$ d.I. & - & 94.54 & 1.53 \\
\hline zrc2-2 & 32.77 & 0.16 & 64.89 & 1.56 & 940 & 80 & 97.76 & 1.57 \\
\hline zrc2-3 & 32.19 & 0.16 & 65.46 & 1.57 & 620 & 80 & 97.71 & 1.58 \\
\hline zrc2-4 & 32.27 & 0.16 & 63.00 & 1.53 & $<$ d.I. & - & 95.27 & 1.54 \\
\hline & \multicolumn{6}{|c|}{ Average $\mathrm{Ti}(\mathrm{ppm})=468$} & \multicolumn{2}{|c|}{$\mathrm{T}\left({ }^{\circ} \mathrm{C}\right)=1122$} \\
\hline zircon type-3 & & & & & & & & \\
\hline zrc3-1 & 32.34 & 0.16 & 66.14 & 1.58 & 510 & 80 & 98.54 & 1.59 \\
\hline zrc3-2 & 35.05 & 0.17 & 55.97 & 1.41 & 1890 & 90 & 91.21 & 1.42 \\
\hline zrc3-3 & 30.97 & 0.16 & 65.47 & 1.57 & 4100 & 110 & 96.85 & 1.57 \\
\hline zrc3-4 & 33.58 & 0.17 & 64.28 & 1.55 & 1380 & 90 & 98.00 & 1.56 \\
\hline & \multicolumn{6}{|c|}{ Average Ti $(\mathrm{ppm})=1182$} & \multicolumn{2}{|c|}{$\mathrm{T}\left({ }^{\circ} \mathrm{C}\right)=1456$} \\
\hline
\end{tabular}

\footnotetext{
${ }^{a}$ spot numbers presented here are not related to SHRIMP spot numbers
}

$<$ d.I. means below detection limit 
